\title{
HUBUNGAN STATUS GIZI DENGAN KEJADIAN PNEUMONIA PADA BALITA
}

\author{
Desi Ernita Amru', Yulia Devi Putri², Anisya Selvia ${ }^{3}$ \\ 1,2,3 Institut Kesehatan Mitra Bunda Batam \\ dhesyamru12@gmail.com
}

\begin{abstract}
ABSTRAK
Salah satu faktor penyebab terjadinya pneumonia pada balita adalah status gizi. Lebih dari 800.000 balita meninggal dunia akibat pneumonia. Angka kejadian pneumonia di Kota Batam tahun 2018 adalah sebanyak 242 balita. Penelitian ini bertujuan untuk mengetahui hubungan status gizi dengan kejadian pneumonia pada balita di Puskesmas Baloi Permai Kota Batam. Jenis penelitian ini adalah penelitian analitik dengan Desain Secondary Data Analysis. Responden dalam penelitian ini adalah balita sebanyak 67 orang, dengan teknik penarikan sampel yang digunakan adalah total sampling. Hasil uji statistik yang digunakana adalah chi-square didapatkan hasil nilai $p$-value $=0,000(<\alpha=0,05)$. Hal ini menunjukkan bahwa ada hubungan status gizi dengan kejadian pneumonia pada balita di Puskesmas Baloi Permai Kota Batam. Para ibu yang memiliki balita sebaiknya dapat memperhatikan status gizinya karena status gizi merupakan salah satu penyebab dari pneumonia.
\end{abstract}

Kata kunci : balita, pneumonia, status gizi

\section{RELATIONSHIP OF NUTRITION STATUS WITH EVENT PNEUMONIA IN TODDLERS}

\begin{abstract}
Nutritional status is one of the factors causing pneumonia in children. More than 800,000 children under five die from pneumonia. The incidence of pneumonia in Batam City in 2018 was 242 children under five. This study aims to determine the relationship between nutritional status and the incidence of pneumonia in toddlers at the Baloi Permai Health Center, Batam City. This type of research is an analytic study with a secondary data analysis design. This study included 67 respondents aged one month - four years, with the sampling technique used random sampling. The statistical test results used chi-square. The results obtained $p$-value $=0.000(<\alpha=0.05)$. It shows a relationship between nutritional status and the incidence of pneumonia in children under five Years at Baloi Puskesmas Batam City in 2020. It is hoped that mothers should recognize that one of the causes of pneumonia is a lack of / poor nutritional status. Mothers with toddlers with pneumonia immediately improve their toddlers' nutritional status, which is done by exclusive breastfeeding.
\end{abstract}

Keywords: nutrition status, pneumonia, toddler 


\section{PENDAHULUAN}

Penyebab kematian utama anak usia di bawah lima tahun (balita) adalah infeksi pernafasan, selain itu gangguan neonatal, asfiksia, cacat bawaan lahir, diare, malaria, meningitis, kekurangan gizi dan pneumonia menjadi penyebab kematian pada balita (Hartono, 2017).

Penyakit batuk dan pilek yang disertai dengan sesak nafas (nafas cepat) yang terjadi pada balita dikarenakan infeksi jaringan paru (alveoli) merupakan defenisi dari pneumonia. (Dahlan, 2014). Infeksi tersebut membuat sulitnya suplai oksigen masuk ke dalam saluran pernafasan anak karena terisi oleh nanah dan cairan sehingga balita menjadi sesak (WHO, 2019).

Profil Kesehatan Indonesia menunjukkan pada tahun 2017 didapatkan angka insiden pneumonia sebesar 46,34\%, sedangkan tahun 2018 kasus pneumonia pada balita sebesar $56,51 \%$ kasus, dan pada balita di Provinsi Kepulauan Riau sebesar 3,98\% kasus (Zulia et al., 2018).

Berdasarkan Data di Kota Batam tahun 2017 balita yang menderita pneumonia sebanyak 884 kasus, sedangkan tahun 2018 sebanyak 242 kasus balita mengalami pneumonia, pada tahun 2019 jumlah data balita yang mengalami pneumonia di Puskesmas Baloi Permai, Sekupang dan Botania sebanyak 222 balita (Dinas Kesehatan Kota Batam, 2018).

Faktor yang menjadi penyebab kejadian pneumonia antara lain pemberian.ASI yang tidak esklusif, berat.badan anak saat lahir, karakteristik..ibu kurang baik, tidak lengkap status..imunisasi..balita, tidak baik faktor. lingkungan, dan status gizi balita yang tidak baik (A. Hartono, 2015). Penggunaan zat gizi dan makanan yang dikonsumsi seseorang dapat menjadi ukuran untuk menilai bagaimana status gizinya. (Nasar, Djoko, 2014).

Pada Profil Kesehatan Republik Indonesia tahun 2018 terdapat 3, 9\% balita mengalami gizi buruk, dan 13,8\% mengalami gizi kurang. Di Kepulauan Riau balita dengan masalah gizi buruk sebesar 3,2\%, sedangkan gizi kurang 9,8\% (Kemenkes RI, 2019).

Dampak dari penyakit pneumonia (radang paru-paru) pada anak usia balita bisa sampai menyebabkan kematian (PDPI, 2014)... Adapun dampak penyakit pneumonia dapat menjadi menyebabkan kematian dan kecacatan pada anak (Halim Danusantoso, 2014)..Namun demikian, penanggulangan penyakit tersebut masih belum mendapat perhatian (Kementrian Kesehatan Republik Indonesia, 2011).

Tujuan dari penelitian ini untuk melihat hubungan status gizi terhadap kejadian pneumonia pada balita di Kota Batam.

\section{METODOLOGI.}

Jenis penelitian adalah penelitian analitik dengan rancangan observasional retrospektif meggunakan secondary data analysis (Juliansyah, 2017). Secondary data analysis merupakan strategi penelitian menggunakan data yang sudah ada (Sugiono, 2017). Pemilihan data ini dipilih karena penelitian dilakukan pada masa pandemi Covid-19 sehingga pihak Puskesmas Baloi Permai tidak mengizinkan peneliti untuk langsung bertemu dengan pasien. Penelitian bertempat di Puskesmas Baloi Permai Kota Batam. Instrumen pengumpulan data yaitu menggunakan data sekunder (Sugiyono, 2011). Populasi dalam penelitian ini adalah seluruh balita yang datang ke Puskesmas Baloi Permai pada bulan Januari - Juni Tahun 2020 berjumlah 67 orang. Penarikan sampel menggunakan teknik total sampling.

\section{HASIL}

Berdasarkan hasil penelitian mengenai hubungan status gizi dengan kejadian pneumonia 
di Puskesmas Baloi Permai Kota Batam didapatkan hasil sebagai berikut.

Tabel 1. Karakteristik Frekuensi Balita Berdasarkan Umur

\begin{tabular}{|c|c|c|}
\hline Umur & $\mathbf{n}$ & $\%$ \\
\hline 1 bulan -1 tahun & 33 & 49,3 \\
\hline$>1$ tahun -2 tahun & 14 & 20,9 \\
\hline$>2$ tahun -3 tahun & 16 & 23,9 \\
\hline$>3$ tahun -4 tahun & 4 & 6,4 \\
\hline Total & 67 & 100 \\
\hline
\end{tabular}

Berdasarkan tabel 1 diketahui bahwa balita di Puskesmas Baloi Permai sebagian besar berumur 1 bulan -1 tahun. Retang usia tersebut sebanyak $33(49,3 \%)$.

Tabel 2. Karakteristik Frekuensi Balita Berdasarkan Jenis Kelamin

\begin{tabular}{ccc}
\hline Jenis Kelamin & n & \% \\
\hline Perempuan & 37 & 55,2 \\
Laki-Laki & 30 & 44,8 \\
\hline Total & $\mathbf{6 7}$ & $\mathbf{1 0 0}$ \\
\hline
\end{tabular}

.Berdasarkan tabel 2 diketahui bahwa balita di Puskesmas Baloi Permai sebagian besar berjenis kelamin perempuan. Jenis kelamin perempuan sebanyak 37 (55,2\%).

Tabel 3. Katakteristik Frekuensi Balita Berdasarkan Berat Badan di Puskesmas Baloi Permai Kota Batam Tahun 2020

\begin{tabular}{ccc}
\hline Berat Badan & n & $\mathbf{\%}$ \\
\hline $1-5 \mathrm{~kg}$ & 5 & 7,2 \\
$>5-10 \mathrm{~kg}$ & 43 & 64,2 \\
$>10-15 \mathrm{~kg}$ & 13 & 19,4 \\
$>15-20 \mathrm{~kg}$ & 5 & 7,5 \\
$>20-25 \mathrm{~kg}$ & 1 & 1,5 \\
\hline Total & $\mathbf{6 7}$ & $\mathbf{1 0 0}$ \\
\hline
\end{tabular}

Berdasarkan tabel 3 diketahui bahwa balita di Puskesmas Baloi Permai sebagian besar memiliki berat badan $>5-10 \mathrm{~kg}$. Berat badan $>5$ - $10 \mathrm{~kg}$ berjumlah 43 (64,2\%).

Tabel 4. Distribusi Frekuensi Balita Berdasarkan Status Gizi di Puskesmas Baloi Permai Kota Batam Tahun 2020

\begin{tabular}{ccc}
\hline Status Gizi & n & $\mathbf{\%}$ \\
\hline Buruk & 17 & 25,4 \\
Kurang & 18 & 26,9 \\
Lebih & 12 & 17,9 \\
Baik & 20 & 29,9 \\
\hline Total & $\mathbf{6 7}$ & $\mathbf{1 0 0}$ \\
\hline
\end{tabular}

Berdasarkan tabel 4 diketahui bahwa balita di Puskesmas Baloi Permai sebagian besar dengan status gizi baik. Status baik berjumlah $20(29,9 \%)$.

Tabel 5. Distribusi Frekuensi Balita Berdasarkan Pneumonia di Puskesmas Baloi Permai Kota Batam Tahun 2020

\begin{tabular}{clc}
\hline Status Gizi & $\mathbf{n}$ & $\mathbf{\%}$ \\
\hline Pneumonia & 38 & 56,7 \\
Tidak Pneumonia & 29 & 43,3 \\
\hline Total & $\mathbf{6 7}$ & $\mathbf{1 0 0}$ \\
\hline
\end{tabular}

Berdasarkan tabel 5 diketahui balita di Puskesmas Baloi Permai sebagian besar dengan pneumonia. Jumlah balita dengan pneumonia tersebut sebanyak $40(59,7 \%)$. 


\section{Tabel 6. Hasil Distribusi Hubungan Status Gizi dengan Kejadian Pneumonia pada Balita di Puskesmas Baloi Permai Kota Batam Tahun 2020}

\begin{tabular}{cccccccc}
\hline \multirow{2}{*}{ Status Gizi } & \multicolumn{9}{c}{ Pneumonia } & \multicolumn{3}{c}{ Frekuensi } & \multirow{2}{*}{ p-value } \\
\cline { 2 - 6 } & Pneumonia & $\mathbf{\%}$ & $\begin{array}{c}\text { Tidak } \\
\text { Pneumonia }\end{array}$ & $\mathbf{\%}$ & $\mathbf{n}$ & $\mathbf{\%}$ & \\
\hline Buruk & 13 & 76,5 & 4 & 23,5 & 17 & 100 & \\
Kurang & 18 & 100,0 & 0 & 0 & 18 & 100 & \\
Lebih & 5 & 41,7 & 7 & 58,3 & 12 & 100 & 0,000 \\
Baik & 2 & 10,0 & 18 & 90,0 & 20 & 100 & \\
\hline Total & $\mathbf{3 8}$ & $\mathbf{5 6 , 7}$ & $\mathbf{2 9}$ & $\mathbf{4 3 , 3}$ & $\mathbf{6 7}$ & $\mathbf{1 0 0}$ & \\
\hline
\end{tabular}

Berdasarkan tabel 6 diketahui bahwa dari 67 balita terdapat balita berstatus gizi buruk dengan pneumonia sebanyak 13 responden (76,5\%), sedangkan yang tidak pneumonia berjumlah 4 responden $(23,5 \%)$. Balita dengan status gizi kurang dengan pneumonia berjumlah 18 responden (100,0\%), sedangkan yang tidak pneumonia berjumlah 0 responden $(0 \%)$. Balita dengan status gizi lebih dengan pneumonia berjumlah 5 responden $(41,7 \%)$, sedangkan yang tidak pneumonia berjumlah 7 responden $(58,3 \%)$. Balita dengan status gizi baik dengan pneumonia berjumlah 2 responden (10,0\%), sedangkan yang tidak pneumonia berjumlah 18 (90,0\%). Hasil analisis uji statistik diketahui bahwa nilai $p$-value adalah $0,000<0,05$ artinya terdapat hubungan status gizi dengan kejadian pneumonia pada balita di Puskesmas Baloi Permai Kota Batam.

\section{PEMBAHASAN}

Berdasarkan hasil penelitian di Puskesmas Baloi Permai Kota Batam ditunjukkan bahwa dari 67 balita memiliki status gizi buruk dengan pneumonia berjumlah 13 responden (76,5\%), balita dengan status gizi kurang dengan pneumonia berjumlah 18 responden $(100,0 \%)$, selanjutnya balita dengan status gizi baik sebanyak 20 (29,9\%). Balita dengan status gizi lebih dengan pneumonia berjumlah 5 responden
(41,7\%) sedangkan yang tidak pneumonia berjumlah 7 responden $(58,3 \%)$. Pneumonia biasanya terjadi pada balita dengan gizi buruk, namun demikian balita dengan gizi lebih juga dapat mengalami pneumonia. Hal ini terjadi disebabkan oleh bakteri yang masuk ke tubuh balita.

Salah satu faktor risiko terjadinya pneumonia pada balita dapat dinilai dari status gizi balita. Risiko terjadinya pneumonia lebih besar terjadi pada balita dengan gizi kurang dan gizi buruk (Riyadi, Sujono, 2012). Suatu ukuran mengenai kondisi tubuh seseorang yang dapat dilihat dan dinilai dari makanan yang dikonsumsi serta berbagai penggunaan zat-zat gizi di dalam tubuh dikenal dengan istilah status gizi (Maramis, 2016).

Penelitian ini sejalan dengan penelitian yang dilakukan oleh Mia Nurnajiah, Rusdi, dan Desmawati (tahun 2016) tentang "Hubungan Status Gizi dengan Pneumonia pada Balita di RS. Dr. M. Djamil Padang" menujukkan sebanyak 51 balita $(91,1 \%)$ dengan status gizi baik menderita pneumonia dan 18 balita $(8,9 \%)$ status gizi kurangburuk menderita pneumonia. Hasil Penelitan Sarlis dan Filda (2018) di Puskesmas Umban Sari Pekanbaru sejalan dengan hasil penelitain ini bahwa sebagian.besar.balita berstatus gizi yang baik sebanyak 41 balita (21\%) (Nurnajiah 
et al., 2016). Banyak faktor yang dapat menjadi penyebab terjadinya pneumonia, salah satunya gizi, tetapi apabila gizi balita baik, lingkungan tidak mendukung (terpapar asap rokok) tidak mendapatkan ASI ekslusif juga dapat membuat rentan balita terkena Pnemonia (Indri Kurnia Dewi, and Nanik Setiyawati, Dwiana Estiwidani, 2018).

Penelitian Sulistyaningsih dan ayun (2014) di Puskesmas Piyungan Bantul juga menunjukkan ada hubungan antara status gizi dengan kejadian pneumonia. Baik keadaan gizi kurang maupun buruk dapat menjadi penyebab terjadinya pneumonia. Balita yang gizi kurang akan lebih mudah terserang pneumonia dibandingkan balita gizi normal karena faktor daya tahan tubuh yang kurang (Kurratun Ayu, 2015).

Status kurang gizi dapat memengaruhi pembentukan antibodi dan pertahanan paru. Hal ini yang membuat status gizi menjadi penyebab pneumonia pada balita (Wong, 2016).

Status gizi pada balita berpengaruh terhadap ketahanan tubuh balita (Roesli Utami, 2013). Reaksi kekebalan tubuh dan kemampuan untuk mempertahankan diri akan menurun jika gizi buruk. (Siti Husaidah, Desi Ernita Amru, 2020).

Perkembangan seorang anak di masa depan sangat dipengaruhi oleh usianya pada masa balita. Jika anak balita rentan terhadap penyakit dapat mengakibatkan kematian. Sebagian besar penyebab kematian tersebut dikarenakan penyakit seperti: pneumonia (ISPA), diare, malaria, campak, dan malnutrisi (Ahyani, Dwi AstutiNur, 2018).

\section{SIMPULAN DAN SARAN}

Dari Hasil penelitian di dapatkan nilai p-value $0,000<0,05$ sehingga terdapat hubungan antara status gizi dengan kejadian pneumonia pada balita di Puskesmas Baloi Permai Kota
Batam tahun 2020. Bagi para ibu yang memiliki balita diharapkan agar lebih aktif dan cermat dalam mencari informasi tentang makanan yang tepat dan tentunya dapat memenuhi status gizi balita tanpa menunggu adanya penyuluhan dari tenaga kesehatan tentang status gizi yang baik. Selain itu, para ibu diharapkan dapat memperhatikan asupan makanan untuk balita. sehingga status gizi balita menjadi baik dan dapat mencegah terjadinya penyakit infeksi pada balita khususnya pneumonia. Para ibu juga sebaiknya mengetahui dan mengenali salah satu penyebab pneumonia adalah kurang/buruk status gizi pada balita. Dengan demikian, para ibu yang mempunyai balita, khusunya balita dengan pneumonia dapat segera memperbaiki status gizi balitanya agar pneumonia tersebut segera teratasi dengan terbentuknya sistem imun yang lebih baik.

\section{DAFTAR PUSTAKA}

A. Hartono. (2015). Terapi Gizi dan Diet Rumah Sakit. EGC.

Adriani, M. (2016). Pengantar Gizi Masyarakat. Kencana Prenada Media.

Ahyani, Dwi AstutiNur, L. (2018). Buku Ajar Psikologi Perkembangan Anak dan Remaja. Universitas Muria Kudus.

Dahlan, z. (2014). Pneumonia : Buku Ajar Ilmu Penyakit Dalam Jilid 2. Fakultas Kedokteran Universitas Indonesia.

Dinas Kesehatan Kota Batam. (2018). Profil

Kesehatan Kota Batam Tahun 2018.

Profil Kesehatan Kota Batam, 54, 38-74.

Halim Danusantoso. (2014). Buku Saku Ilmu

Penyakit Paru Edisi 3. EGC.

Hartono, D. R. (2017). ISPA : Gangguan

Pernafasan Pada Anak cetakan ketiga.

Numed.

Indri Kurnia Dewi, and Nanik Setiyawati,

Dwiana Estiwidani. (2018). Faktor-

Faktor Yang Mempengaruhi Kejadian 
Pneumonia Pada Balita Di Puskesmas

Sentolo 1, Kabupaten Kulon Progo

Tahun 2018.

Juliansyah, N. (2017). Buku Metodelogi

Penelitian Edisi 7. Kencana.

Kemenkes RI. (2019). Profil Kesehatan

Indonesia 2018 [Indonesia Health

Profile 2018]. http://www.depkes.

go.id/resources/download/pusdatin/

profil-kesehatan-indonesia/Data-

dan-Informasi_Profil-Kesehatan-

Indonesia-2018.pdf

Kementrian Kesehatan Republik Indonesia.

(2011). Buku Pedoman Pengendalian

Infeksi Saluran Pernafasan Akut. Bakti

Husada.

Kurratun Ayu. (2015). Hubungan Status Gizi

Dan Vitamin A Dengan Kejadian

Pneumonia Pada Balita Di Puskesmas

Piyungan Bantul.

Maramis. (2016). Buku Ajaran Keperawatan

Gerontik. EGC.

Nasar, Djoko, S. H. (2014). Penuntun Diet

ANak. Badan Penerbit FK UI.

Nurnajiah, M., Rusdi, R., \& Desmawati, D. (2016). Hubungan Status Gizi dengan Derajat Pneumonia pada Balita di RS.

Dr. M. Djamil Padang. Jurnal Kesehatan Andalas, 5(1), 250-255. https://doi. org/10.25077/jka.v5i1.478
PDPI. (2014). Pedoman Diagnosis dan Penatalaksanaan Pnemonia Komunitas di Indonesia. Penerbit FK UI.

Riyadi, Sujono, dkk. (2012). Asuhan Keperawatan Pada Anak Sakit. Penerbit Gosyen Publishing.

Roesli Utami. (2013). Mengenal ASI Eksklusif. Trubus Agriwidya.

Siti Husaidah, Desi Ernita Amru, S. (2020). Hubungan Antara Tingkat Pendidikan Dan Pengetahuan Ibu Nifas Dengan Pemberian Asi Eksklusif Di Puskesmas Batua Makassar 2019. Jurnal Sehat Mandiri, 15(1), 130-139. http://jurnal. poltekkespadang.ac.id/ojs/index.php/ jsm/article/view/162/60

Sugiono. (2017). Metodologi Penelitian. Alfabeta.

Sugiyono. (2011). Metode Penelitian Kuantitatif, Kualitatif dan R\&D. Afabeta.

WHO. (2019). Pneumonia. Agustus. https:// www.who.int/en/news-room/fact-sheets/ detail/pneumonia

Wong, D. L. (2016). Pedoman Klinis Keperawatan Pediatrik. Edisi 7. EGC. Zulia, A., Esti Rahayu, H. S., \& -, R. (2018). Akupresur Efektif Mengatasi Dismenorea. Jurnal Persatuan Perawat Nasional Indonesia (JPPNI), 2(1), 9. https://doi.org/10.32419/jppni.v2i1.78 